\title{
Fibrinolysis in acute myocardial infarction, a historical revaluation?
}

\author{
Fibrinólisis en el infarto agudo de miocardio, ¿una reivindicación histórica?
}

\author{
Sebastián García-Zamora ${ }^{1 *}$ and Andrés Rosende ${ }^{2}$ \\ ${ }^{1}$ Cardiology Department, Fundación para la Lucha contra Enfermedades Neurológicas de la Infancia (FLENI), Buenos Aires; ${ }^{2}$ Cardiovascular \\ Intensive Care Unit, Cardiology Department, Hospital de Alta Complejidad en Red El Cruce, Dr. Néstor C. Kirchner, Florencio Varela. Argentina
}

According to main cardiology societies guidelines, both percutaneous coronary intervention (PCl) and fibrinolysis have the highest degree of evidence for the treatment of acute ST-segment elevation myocardial infarction (STEMI) ${ }^{1,2}$. However, favoring $\mathrm{PCl}$ over fibrinolysis is recommended even when this implies a delay of up to 120 minutes $^{1,2}$. In 2003, a meta-analysis ${ }^{3}$ of 22 studies and 7,739 participants concluded that $\mathrm{PCl}$ reduced 30 -day mortality by approximately $28 \%$ in comparison with fibrinolysis, with non-fatal reinfarction and hemorrhagic stroke rates also being decreased. These results, universally accepted ever since, should be relativized due to methodological limitations of included trials. First, all were open-label studies, which implies a high risk of bias in endpoints with inconsistent and poorly objective definitions, such as reinfarction. Second, most analyzed studies were small, with the benefit of $\mathrm{PCl}$ being concentrated there. There are numerous historical examples of meta-analyses of "small" trials that found benefits that were not subsequently reproduced by large trials ${ }^{4}$; thus did concepts such as "optimal information size" and "fragility" emerge for scrutinizing the results of clinical trials and systematic reviews ${ }^{5}$. Third, in said studies, patients receiving fibrinolytic therapy did not have access to rescue $\mathrm{PCl}$ when fibrinolysis failed. Finally, the time difference between $\mathrm{PCl}$ and fibrinolysis was very small, which magnifies the benefits of the former; in 20 of the 22 trials, this interval was of less than 60 minutes (in one of them, it was even as short as 7 minutes). This contrasts with what is observed in clinical practice, where only a minority of patients are reperfused within the recommended times ${ }^{1,2}$, both in high-income countries and, especially, in those of middle and low-income, as our region ${ }^{6,8}$. In Mexico, the RENASICA III registry informed that half of STEMls received $\mathrm{PCl}$ after more than 100 minutes of admission to a center with hemodynamics unit ${ }^{6}$, while in Peru, PERSTEMI reported a delay between first medical contact (FMC) and reperfusion of 3.6 hours on average ${ }^{7}$ and, in Argentina, according to ARGEN-IAM-ST, only $30 \%$ of patients received angioplasty within the first 90 minutes $^{8}$. The problem is even more serious, considering that $20-45 \%$ of STEMls did not receive any reperfusion treatment ${ }^{6-8}$. Despite these delays, the use of fibrinolytic drugs was low: $37.6 \%$, $38 \%{ }^{7}$ and $16.5 \%{ }^{8}$, respectively.

The reasons for the low utilization of fibrinolytic drugs in our region are diverse, although possibly there is an influence of the fact that they are less recommended in guidelines ${ }^{1,2}$, a belief in the superiority of $\mathrm{PCl}^{3}$ and delays in pre-hospital and intra-hospital transfers in countries with large dimensions and low number of hemodynamics services outside the main metropolitan areas $^{9}$.

So far, the largest clinical trial that has compared fibrinolytic therapy with $\mathrm{PCl}$ is STREAM ${ }^{10}$, which randomized patients with STEMI within 3 hours after symptom onset and who were unable to undergo $\mathrm{PCl}$ within the

\section{Correspondence:}

*Sebastián García-Zamora

E-mail: sebagz83@gmail.com
Date of reception: 11-06-2020

Date of acceptance: 06-08-2020

DOI: 10.24875/ACME.M21000206
Available online: 19-07-2021

Arch Cardiol Mex (Eng). 2021;91(2):226-228

www.archivoscardiologia.com license (http://creativecommons.org/licenses/by-nc-nd/4.0/). 


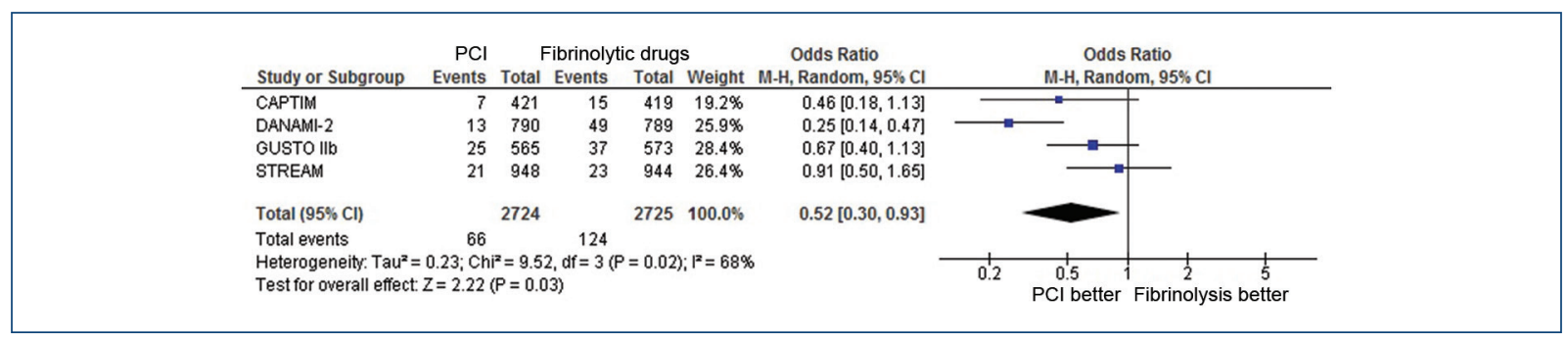

Figure 1. Forest Plot. Analysis of the impact of treatment with percutaneous coronary intervention vs. fibrinolysis on cardiovascular mortality in clinical trials with low risk of biases.

\begin{tabular}{|c|c|c|c|c|c|c|c|c|c|}
\hline \multirow{2}{*}{$\begin{array}{l}\text { Study or Subgroup } \\
\text { CAPTIM }\end{array}$} & \multirow{2}{*}{$\begin{aligned} \begin{aligned} \mathrm{PCl} \\
\text { Events }\end{aligned} \\
20\end{aligned}$} & \multicolumn{3}{|c|}{ Fibrinolytic drug } & Weight & $\begin{array}{c}\text { Risk Ratio } \\
\text { M-H, Random, } 95 \% \mathrm{Cl}\end{array}$ & \multicolumn{3}{|c|}{$\begin{array}{c}\text { Risk Ratio } \\
\text { M-H, Random, } 95 \% \mathrm{Cl}\end{array}$} \\
\hline & & 421 & 16 & 419 & $9.4 \%$ & $1.24[0.65,2.37]$ & & & \\
\hline DANAMI-2 & 52 & 790 & 59 & 789 & $30.1 \%$ & $0.88[0.61,1.26]$ & & 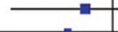 & \\
\hline GUSTO IIb & 32 & 565 & 40 & 573 & $19.2 \%$ & $0.81[0.52,1.27]$ & & & \\
\hline PRAGUE-2 & 29 & 429 & 42 & 421 & $18.9 \%$ & $0.68[0.43,1.07]$ & & & \\
\hline STREAM & 42 & 948 & 43 & 944 & $22.5 \%$ & $0.97[0.64,1.47]$ & & & \\
\hline Total $(95 \% \mathrm{Cl})$ & & 3153 & & 3146 & $100.0 \%$ & $0.87[0.72,1.06]$ & & & \\
\hline \multirow{2}{*}{\multicolumn{6}{|c|}{ 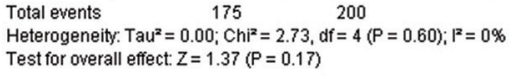 }} & & & & \\
\hline & & & & & & & $\frac{1}{0.5}$ & $\begin{array}{c}0.7 \\
\text { PCl better }\end{array}$ & $\begin{array}{cc}1.5 & 2 \\
\text { Fibrinolysis better }\end{array}$ \\
\hline
\end{tabular}

Figure 2. Forest Plot. Analysis of the impact of treatment with percutaneous coronary intervention vs. fibrinolysis on non-fatal reinfarction in clinical trials with low risk of biases.

first 60 minutes after FMC. There were no differences in mortality between groups (4.4 and $4.6 \%$ ) and neither did the remaining analyzed endpoints differ, including intracranial hemorrhage. Median FMC-to-balloon time in the $\mathrm{PCl}$ group was 86 minutes. As data of interest, $36 \%$ of patients who underwent fibrinolysis required rescue or urgent $\mathrm{PCl}$, which could partially explain the excellent results in the tenecteplase group ${ }^{10}$.

In view of the foregoing, we decided to compare the impact of fibrinolytic therapy on STEMI mortality by carrying out a meta-analysis that included clinical trials with low risk of large biases (sample size close to or larger than 1,000 participants), according to the criterion used to assess the usefulness of fibrinolytic therapy. This way, only four trials from the Keeley et al. ${ }^{3}$ meta-analysis met these criteria, with STREAM being added to these trials. Globally, $\mathrm{PCl}$ was associated with a trend towards a reduction in the risk ratio (RR) for death in STEMI, which did not reach statistical significance (RR: 0.87; 95\% confidence interval: 0.72-1.06; $p=0.17$ ) without heterogeneity, and with a sample size similar to that from Keeley et al. ${ }^{3}(n=6,299)$ (Fig. 1).

In contrast, $\mathrm{PCl}$ was superior in reducing non-fatal reinfarction, but with high heterogeneity $\left(1^{2}=68 \%\right)$, as a result of DANAMI-2 findings (Fig. 2).
These discrepancies with the results obtained by Keeley et al. ${ }^{3}$ suggest the existence of reporting or publication biases in small studies ${ }^{4,5}$ in favor of trials with positive results and centers with a high volume of procedures $^{9}$.

In conclusion, we consider that our results suggest uncertainty regarding the superiority of $\mathrm{PCI}$ for reducing STEMI mortality when fibrinolytic drugs are rapidly administered after FMC, especially within a plan that includes a rescue $\mathrm{PCl}$ strategy when fibrinolysis fails. While $\mathrm{PCl}$ has additional benefits, the reality of our region does not allow for it to be STEMl's main reperfusion strategy. "The golden hour" aphorism is probably more current than ever, and implementing programs based on fibrinolysis for patients who cannot receive $\mathrm{PCl}$ within the first 60 minutes after FMC will reduce mortality from this pathology, with comparable results to those of angioplasty.

\section{Funding}

This research has not received any specific grant from public, commercial or non-profit sector agencies. 


\section{Conflicts of interest}

None.

\section{Ethical disclosures}

Protection of human and animal subjects. The authors declare that no experiments have been performed on humans or animals for this research.

Confidentiality of data. The authors declare that no patient data appear in this article.

Right to privacy and informed consent. The authors declare that no patient data appear in this article.

\section{References}

1. Ibánez B, James $S$, Agewall $S$, Antunes MJ, Bucciarelli-Ducci $C$ Bueno $\mathrm{H}$, et al. 2017 ESC Guidelines for the management of acute myocardial infarction in patients presenting with ST-segment elevation. Rev Esp Cardiol. 2017;70:1082.

2. Levine GN, Bates ER, Blankenship JC, Bailey SR, Bittl JA, Cercek B, et al 2015 ACC/AHA/SCAI Focused Update on Primary Percutaneous Coro- nary Intervention for Patients With ST-Elevation Myocardial Infarction: An Update of the 2011 ACCF/AHA/SCAI Guideline for Percutaneous Coronary Intervention and the 2013 ACCF/AHA Guideline for the Management of ST-Elevation Myocardial Infarction. J Am Coll Cardiol. 2016;67:1235-50

3. Keeley EC, Boura JA, Grines CL. Primary angioplasty versus intravenous thrombolytic therapy for acute myocardial infarction: a quantitative review of 23 randomised trials. Lancet. 2003:361:13-20.

4. LeLorier J, Grégoire G, Benhaddad A, Lapierre J, Derderian F. Discrepancies between meta-analyses and subsequent large randomized, controlled trials. N Engl J Med. 1997;337:536-42.

5. Guyatt GH, Oxman AD, Kunz R, Brozek J, Alonso-Coello P, Rind D, et al. GRADE Guidelines 6. Rating the Quality of Evidence-Imprecision. J Clin Epidemiol. 2011;64:1283-93.

6. Martínez-Sánchez C, Borrayo G, Carrillo J, Juárez U, Quintanilla J, Jerjes-Sánchez C; RENASICA III Investigators. Clinical management and hospital outcomes of acute coronary syndrome patients in Mexico: The Third National Registry of Acute Coronary Syndromes (RENASICA III) Arch Cardiol Mex. 2016;36:221-32.

7. Chacón-Díaz M, Vega A, Aráoz O, Ríos P, Baltodano R, Villanueva F, et al. Epidemiological characteristics of ST-segment elevation myocardial infarction in Peru: results of the PEruvian Registry of ST-segment Elevation Myocardial Infarction (PERSTEMI). Arch Cardiol Mex. 2018;88:403-12.

8. Cohen Arazi H, Zapata G, Marturano MP, De la Vega MB, Pellizón OA Imperio $\mathrm{H}$, et al. Primary angioplasty in Argentina. Results from ARGENIAM-ST Registry. Medicina (B Aires). 2019;79:251-6.

9. Martínez-Sánchez C, Arias-Mendoza A, González-Pacheco H, Araiza-Garaygordobil D, Marroquín-Donday LA, Padilla-lbarra J, et al. Reperfusion therapy of myocardial infarction in Mexico: a challenge for modern cardiology. Arch Cardiol Mex. 2017;87:144-50.

10. Armstrong PW, Gershlick AH, Goldstein $P$, Wilcox R, Danays $T$, Lambert $\mathrm{Y}$, et al. Fibrinolysis or primary $\mathrm{PCl}$ in ST-segmen 